But at the moment, I think, our best chance of overcoming the serious predicament of lack of recruits in endocrinology is to encourage the establishment and expansion of the endocrine aspects of certain branches of the medical sciences which cannot afford to ignore endocrinology if they are to make their proper contributions and retain their high reputation in this age of rapid scientific advances. I will take two examples to illustrate what I mean. The first is paediatrics. Lawson Wilkins has shown the close relationship between paediatrics and endocrinology, and through his inspiration, enthusiasm, and hard work he has made farreaching contributions, not only to paediatrics, but to endocrinology. He has broadened the scope of paediatrics and, far from snatching the livelihood from the mouths of the paediatricians, he has presented them with a new stock-intrade, and on account of his work and that of others like him paediatricians throughout the world are being consulted more and more about endocrine problems. If the paediatricians of this country would select and encourage one or two of their promising young registrars and have them fully and carefully trained as endocrinologists, and then be prepared to give them consultant status with charge of beds and full responsibility for the care of patients, I feel sure that this step would redound to the credit of British paediatrics. My other example is gynaecology. In my view there is need for more gynaecological endocrinologists. In the first place, disorders of menstruation constitute a rather complex aspect of applied physiology which can be thoroughly comprehended only by someone with a fair knowledge of general endocrinology and biochemistry, and it is seldom that the gynaecologist has this knowledge. His training and outlook are totally different. The surgical skill and technique of the gynaecologist, the mechanical manipulations of the obstetrician, and the necessarily rapid repetition of pelvic examinations in the out-patient clinic are unlike the careful recording of menstrual cycles and the precise timing in relation to the menstrual cycle of endocrine therapy, familiarity with the dosage, potency, toxicity and efficacy of different preparations, and the complementary activities of the adjoining endocrine laboratory unit. Nevertheless endocrinology is playing an increasing part in gynaecology. Let the gynaecologists single out and encourage a few of their promising young registrars and have them fully trained as endocrinologists, and then appoint them with consultant rank to gynaecological professorial units or special gynaecological hospitals. Then give them an endocrine laboratory, and they will provide an added stimulus to the work and enhance the reputation of the department or hospital concerned.

I have chosen only two examples: I could develop my theme further. Clinical endocrinologists are needed in thyroid clinics, fertility clinics, and departments of internal medicine, rheumatology, urology, dermatology, allergy, and even surgery. They may be purely clinical endocrinologists with a background training in either physiology or internal medicine, or they may be recruited from the ranks of the specialty on to which it is intended to graft endocrinology. In either case they should have full consultant status. This is not, in my view, an unrealistic dream. It needs enlightened boards of governors and tolerant and sympathetic medical committees, and heads of departments with a determination to carry out their plan. Unless in some such way consultant posts are created soon, endocrinology in this country will surely wither.

The British Journal Photographic Almanac for 1955 (Henry Greenwood and Co., 5s., or cloth-bound 7s. 6d.) has several articles on recent progress, both in techniques and apparatus, which will be of interest in hospital radiography departments. It is pointed out how much radiography has benefited from new advances in isotope production, and how photochemistry is helping to unravel complex chemical problems. A six-page table gives summary information about materials for medical photography. The photogravure reproductions are excellent.

\section{PNEUMOCOCCAL MENINGITIS}

\section{A SHORT SURVEY OF 78 PATIENTS IN THE BRISTOL CLINICAL AREA}

\author{
BY
}

\author{
C. D. R. PENGELLY, M.B., M.R.C.P. , \\ M.R.C.P.Ed.
}

Senior Medical Registrar, West Cornwall Clinical Area; lately Medical Registrar, Bristol Royal Infirmary

In general the prognosis in pneumococcal meningitis has been poor ; indeed, before the availability of the sulphonamides it was almost hopeless, $100 \%$ mortality having been recorded by Toomey and Roach (1939) and Silverthorne (1948), and a review of 631 cases from the literature revealed but one survival (Waring and Weinstein, 1948). After the introduction of the sulphonamides the mortality remained at about 60 to $80 \%$ (Table I), but marked improvement followed the introduction of penicillin, although very varied results have been reported (Table II). In some the mortality is $20 \%$ or less, but the average for the results quoted is $40 \%$ (Table II).

TABle I.-Mortality of Pneumococcal Meningitis Treated with Sulphonamides Alone (Various Authors)

\begin{tabular}{|c|c|c|c|}
\hline Authors & & $\begin{array}{c}\text { No. of } \\
\text { Cases Treated }\end{array}$ & Mortality \\
\hline 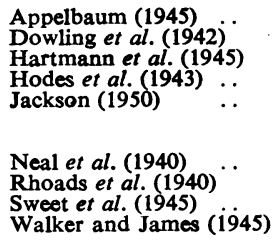 & $\begin{array}{l}. \\
\because \\
\because \\
.\end{array}$ & $\begin{array}{c}139 \\
72 \\
34 \\
60 \\
82 \text { (excluding those } \\
\text { treated with sul- } \\
\text { phanilamide only) } \\
30 \\
22 \\
40 \\
28 \text { (one patient treated } \\
\text { with penicillin) }\end{array}$ & $\begin{array}{l}65 \% \\
94 \% \\
63 \% \\
58 \% \\
79 \% \\
\\
\\
67 \% \\
68 \% \\
92 \% \\
64 \%\end{array}$ \\
\hline
\end{tabular}

TABLE II.-Mortality of Published Series of Cases of Pneumococcal Meningitis Treated with Penicillin

\begin{tabular}{|c|c|c|}
\hline Authors & No. of Cases & Mortality \\
\hline $\begin{array}{l}\text { Appelbaum and Nelson (1945) } \\
\text { Appelbaum } \text { et al. (1949) } \\
\text { Bunn and Peabody (1952) }\end{array}$ & $\begin{array}{r}67 \\
125 \\
20\end{array}$ & $\begin{array}{l}61 \% \\
26 \% \\
35 \%(25 \% \text { if } 2 \text { patients } \\
\text { who died during } \\
\text { treat ment from } \\
\text { other causes are } \\
\text { excluded) }\end{array}$ \\
\hline 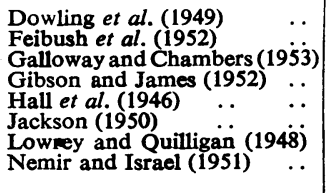 & $\begin{array}{c}87 \\
22 \\
27 \\
31 \\
17 \\
51 \\
17 \\
\\
15 \text { (all infants and } \\
\text { children) }\end{array}$ & $\begin{array}{l}56 \% \\
68 \% \\
33 \% \\
10 \% \\
24 \% \\
43 \% \\
18 \% \\
7 \%\end{array}$ \\
\hline 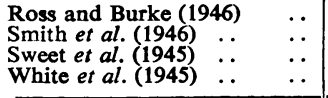 & $\begin{array}{l}19 \\
38 \\
16 \\
50\end{array}$ & $\begin{array}{l}16 \% \\
24 \% \\
56 \% \\
64 \%\end{array}$ \\
\hline Total .. & 602 & $40 \%$ \\
\hline
\end{tabular}

\section{Present Series}

During the period January 1, 1946, to May 31, 1953, pneumococcal meningitis was diagnosed in 78 patients in hospitals for acute cases in Bristol. Hospitals for chronic cases were not included in the survey. A number of recurrences brought the total number of attacks of meningitis to 84 , in $82 \%$ of which the pneumococcus was cultured from the C.S.F. either in life or at necropsy, and in the remainder it was seen in a stained smear.

Mortality.-Of the 78 patients 38 died, a mortality of $49 \%$. A necropsy was performed on $28(74 \%)$. The mortality calculated according to the number of attacks of meningitis was $45 \%$. 
Age Distribution.-The age distribution of the patients in 10-year periods is shown in Table III. In addition the period from birth to 1 year of age is included. The

TABLE III.-Age Distribution of 78 Cases of Pneumococcal Meningitis in Bristol

\begin{tabular}{|c|c|c|c|c|c|}
\hline Age & & $\begin{array}{l}\text { No. of } \\
\text { Patients }\end{array}$ & $\begin{array}{c}\text { No. } \\
\text { Dying }\end{array}$ & $\begin{array}{l}\text { No. } \\
\text { Recovering }\end{array}$ & Mortality \\
\hline 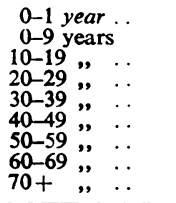 & $\begin{array}{l}. \\
\cdots \\
\ldots \\
\cdots \\
\cdots \\
\cdots \\
\cdots \\
.\end{array}$ & $\begin{array}{r}20 \\
42 \\
6 \\
2 \\
9 \\
3 \\
7 \\
8 \\
1\end{array}$ & $\begin{array}{r}7 \\
15 \\
3 \\
1 \\
5 \\
1 \\
7 \\
5 \\
1\end{array}$ & $\begin{array}{r}13 \\
27 \\
3 \\
1 \\
4 \\
2 \\
0 \\
3 \\
0\end{array}$ & $\begin{array}{r}35 \% \\
36 \% \\
50 \% \\
50 \% \\
55 \% \\
30 \% \\
100 \% \\
62 \% \\
100 \%\end{array}$ \\
\hline Total & .. & 78 & 38 & 40 & $49 \%$ \\
\hline
\end{tabular}

mortality for each age group is shown. Notable features are the relatively large number of infants and children under 10 years old and the steep rise in mortality for those patients aged 50 and over. Only 3 recoveries occurred in 15 patients in the latter group (82\% mortality). For infants the mortality was $35 \%$, or rather below the average $(49 \%)$.

Cause of Meningitis.-In many of the patients there was a demonstrable primary focus of infection, in some it was apparent during life and in others only at necropsy. In a few trauma was the immediate cause and in a large group no cause was found (Table IV). Cases with a clear terminal

TABLE IV.-Apparent Primary Cause of Meningitis in 78 Patients

\begin{tabular}{|c|c|c|c|c|}
\hline $\begin{array}{c}\text { Apparent } \\
\text { Primary Cause }\end{array}$ & $\begin{array}{l}\text { No. of } \\
\text { Patients }\end{array}$ & $\begin{array}{c}\text { No. } \\
\text { Dying }\end{array}$ & $\begin{array}{l}\text { No. } \\
\text { Recovering }\end{array}$ & Mortality \\
\hline \multirow{3}{*}{$\begin{array}{l}\text { Middle ear or mas- } \\
\text { toid infection .. } \\
\text { Pneumonia } \\
\text { Nasal sinus infec- } \\
\text { tion } \\
\text { Panophthalmitis .. } \\
? \text { Bacterial endo- } \\
\text { carditis } \\
\text { Trauma } \\
\text { No cause found .. }\end{array}$} & $\begin{array}{r}30 \\
8\end{array}$ & $\begin{array}{r}12 \\
4\end{array}$ & $\begin{array}{r}18 \\
4\end{array}$ & $50 \%$ \\
\hline & $\begin{array}{l}3 \\
1\end{array}$ & $\begin{array}{l}3 \\
0\end{array}$ & $\begin{array}{l}0 \\
1\end{array}$ & $100 \%$ \\
\hline & $\begin{array}{r}1 \\
9 \\
26\end{array}$ & $\begin{array}{r}0 \\
4 \\
15\end{array}$ & $\begin{array}{r}1 \\
5 \\
11\end{array}$ & $\begin{array}{l}0 \% \\
\quad 44 \% \\
58 \%\end{array}$ \\
\hline Total & 78 & 38 & 40 & $49 \%$ \\
\hline
\end{tabular}

bronchopneumonia only have been excluded from the " pneumonia " group. In the "trauma " group six had head injuries, in two the meningitis followed nasal operations, and in one it followed a perforating injury of one internal ear.

Level of Consciousness on Admission to Hospital.-In 37 of the attacks the patient was either fully conscious or at worst stuporous on admission to hospital, and death followed in 9 ( $24 \%$ mortality). In 31 attacks the patient was delirious or comatose when admitted and death followed in 19 (61\% mortality). In 12 attacks continuous convulsions were occurring at the time of admission and death followed in $8(66 \%$ mortality). (Two attacks occurring in patients

TABLe V.-Distribution of Attacks of Pneumococcal Meningitis According to the Length of Illness. Before Admission to Hospital*

\begin{tabular}{|c|c|c|c|c|}
\hline $\begin{array}{c}\text { No. of Days' } \\
\text { Ilness before } \\
\text { Admission } \\
\text { to Hospital }\end{array}$ & $\begin{array}{c}\text { No. of } \\
\text { Attacks } \\
\text { of } \\
\text { Meningitis }\end{array}$ & $\begin{array}{c}\text { No. of } \\
\text { Attacks with } \\
\text { Fatal } \\
\text { Outcome }\end{array}$ & $\begin{array}{c}\text { No. of } \\
\text { Attacks } \\
\text { with } \\
\text { Recovery }\end{array}$ & Mortality \\
\hline 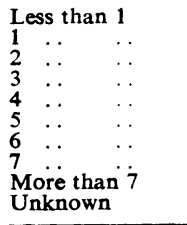 & $\begin{array}{r}10 \\
18 \\
9 \\
15 \\
5 \\
4 \\
1 \\
7 \\
8 \\
3\end{array}$ & $\begin{array}{r}7 \\
10 \\
6 \\
1 \\
2 \\
2 \\
0 \\
2 \\
3 \\
3\end{array}$ & $\begin{array}{r}3 \\
8 \\
3 \\
14 \\
3 \\
2 \\
1 \\
5 \\
5 \\
0\end{array}$ & $\begin{array}{l}70 \% \\
56 \% \\
67 \% \\
7 \% \\
40 \% \\
50 \% \\
0 \% \\
29 \% \\
37 \% \\
100 \%\end{array}$ \\
\hline Total & 80 & 36 & 44 & $45 \%$ \\
\hline
\end{tabular}

* Excluding four attacks, two of which developed in patients who were being treated in hospital for another condition and two in patients transferred from outside the area for operation. transferred to the area for operation and two in patients admitted to hospital for a condition other than meningitis have not been included.)

Duration of Illness Before Admission to Hospital.-An analysis of attacks according to the number of days of illness before the patient's admission to hospital is shown in Table V.

\section{Treatment}

\section{Chemotherapy and Antibiotics}

Table VI shows the sulphonamide and antibiotic treatment given. There are four groups : the first, designated "standard therapy," consists of attacks treated with a sulphonamide together with penicillin by both the intramuscular and the intrathecal routes. Group 2, designated

TABlE VI.-Sulphonamide and Antibiotic Treatment of 84 Attacks of Pneumococcal Meningitis

\begin{tabular}{|c|c|c|c|c|}
\hline Treatment & $\begin{array}{c}\text { No. of } \\
\text { Attacks } \\
\text { of } \\
\text { Meningitis }\end{array}$ & $\begin{array}{c}\text { No. of } \\
\text { Attacks with } \\
\text { Fatal } \\
\text { Outcome }\end{array}$ & $\begin{array}{l}\text { No. of } \\
\text { Attacks } \\
\text { with } \\
\text { Recovery }\end{array}$ & Mortality \\
\hline $\begin{array}{l}\text { 1. Standard treat- } \\
\text { ment } \\
\text { 2. Incomplete treat- } \\
\text { ment } \\
\text { 3. Additional treat- } \\
\text { ment } \\
\text { 4. No specific } \\
\text { treatment }\end{array}$ & $\begin{array}{r}14 \\
13 \\
3\end{array}$ & $\begin{array}{r}20 \\
11 \\
4 \\
3\end{array}$ & $\begin{array}{r}34 \\
3 \\
9 \\
0\end{array}$ & $\begin{array}{r}37 \% \\
79 \% \\
31 \% \\
100 \%\end{array}$ \\
\hline Total & 84 & 38 & 46 & $45 \%$ \\
\hline
\end{tabular}

Occasionally one of the items of the "standard" treatment was omitted in patients in group 3 .

"incomplete therapy," contains those attacks treated as in group 1 but incomplete in some respect-for example, no sulphonamide, no intrathecal penicillin, etc. Group 3 shows those attacks treated as in the preceding groups, but with one or more additional antibiotic. Group 4 shows those attacks not specifically treated.

The additional therapy in Group 3 consisted of intramuscular streptomycin in two attacks, intrathecal streptomycin in two, chlortetracycline (orally) in four, chloramphenicol (orally) in two, and chlortetracycline (orally) with intrathecal streptomycin in one.

The majority of patients receiving penicillin were given an intrathecal dosage of 5,000 to 30,000 units, once or at most twice daily. In two cases 500,000 units was given in error at a single injection and in both death followed within 24 hours preceded by generalized convulsions. Sulphonamides were used as for any acute infection, and intramuscular penicillin was given in a dosage which varied from about 100,000 to $1,000,000$ units in 24 hours divided usually into three- or four-hourly doses. In 45 attacks under 250,000 units in 24 hours was given, and in the remaining 39 more than this amount was used. The mortality was $45 \%$ in the group receiving the smaller amount and $46 \%$ in that receiving the bigger dose. If the 10 attacks in which no penicillin was given intrathecally are excluded from the lower-dosage group the mortality in the remaining 35 attacks was $34 \%$. Two of the patients receiving no intrathecal penicillin recovered.

\section{Surgical Measures}

The operation of mastoidectomy was performed five times in the series, being done $38,8,7$, and 2 days after the patient's admission to hospital in the four cases which recovered. In the one fatal case, that of a baby aged 4 months, it was done on the day of admission. Burrholes were made in the skull for penicillin administration after the development of a block in the spinal theca on three occasions; one patient recovered. In one of the others the meningitis was apparently controlled after this treatment, but the patient remained comatose and died possibly with a cerebral abscess; there was no necropsy. Three further patients were investigated by ventriculography to exclude an intracranial abscess, but none was found. One had developed a right arm paresis which slowly recovered, and the other two were recurrent cases and are mentioned below. 


\section{Recurrent Cases}

In five patients in the series recurrences occurred. In one, that of a boy aged 8 years when he had his first attack in 1947, recurrences occurred five times, with long intervals between attacks. Only in the first was an infective focus discovered and this eliminated by mastoidectomy. The second patient, a man aged 30 , was reinfected through defects in the floor of the anterior cranial fossa. Removal of nasal polypi and a bilateral Horgan's operation were carried out in 1949, following which he had C.S.F. rhinorrhoea. Three weeks after the operation he developed a purulent meningitis from which no organisms were isolated. Two months later a proved attack of pneumococcal meningitis occurred, and after preliminary medical treatment an exploration revealed a hole in the right side of the floor of the anterior cranial fossa which was covered by a graft. After 18 months of good health another attack of pneumococcal meningitis occurred and yet another six months later. In March, 1951, further exploration revealed another hole in the floor of the anterior cranial fossa, this time on the left side, which was also covered by a graft. He remained free from further attacks of meningitis following this, only to die in May, 1953, from a spindle-cell sarcoma arising in his abdominal wall.

The third patient, a lad aged 16, was admitted to hospital with a purulent meningitis the day following a minor head injury in January, 1949 ; there was no radiological evidence of fracture. No organism was isolated. After a rapid recovery he remained well until 18 months later, when he had a proved attack of pneumococcal meningitis. A good response to medical treatment occurred and he has remained well since.

The fourth patient, a man aged 30, was admitted to hospital with pneumococcal meningitis after a history of 24 hours' headache and vomiting. He was in coma. He responded to treatment and no focus of infection was discovered. He remained well until four years later, when he had another attack, coma occurring only a few hours after the onset of headache. In spite of early treatment he died within 24 hours of admission. Necropsy revealed a purulent meningitis and an astrocytoma of the mid-brain causing obstruction of the aqueduct and internal hydrocephalus. There was no infective focus.

The last patient, a girl aged 16, had a splenectomy for Banti's disease at the age of 12 years and developed a meningitis one year later. No organisms were isolated. An attack of pneumococcal meningitis occurred after another two years (1950) and failed to respond well to medical treatment. She was therefore transferred to the Bristol Neurosurgical Unit for investigation, where ventriculograms were negative and the meningitis slowly responded to continued sulphonamide and penicillin therapy. A relapse occurred as soon as treatment was stopped, but she responded well to chloramphenicol. The presence of an apical systolic murmur in her heart suggested the presence of bacterial endocarditis and she was accordingly given a six-weeks course of penicillin, 2,000,000 units a day. She remained well until 1952, when she died at home after a short illness, possibly another attack of meningitis.

\section{Associated Diseases and Conditions}

The meningitis was found in association with other conditions in 10 cases: diabetes mellitus twice, Parkinsonism, cirrhosis of the liver, astrocytoma of the mid-brain, hydronephrosis and chronic pyelonephritis, right upper lobe bronchiectasis, Banti's disease, situs inversus totalis, and familial acholuric jaundice. All except the last two of these patients died.

\section{Discussion}

The present series of cases of pneumococcal meningitis is entirely unselected and includes patients already suffering from a serious disease, which accounts for the high mortality. If only those attacks in which full sulphonamide and penicillin therapy was given are considered the mortality is $37 \%$ of 54 attacks (Table VI), and, furthermore, excluding those cases in which death occurred within 24 hours of admission to hospital, the mortality becomes $28 \%$ of 43 attacks, a figure comparable with all but the very best results (Table II).

Age is a very important factor in relation to prognosis in the disease, particularly poor results occurring in patients aged 50 or more. This is not only the impression from the present series (Table III) but has also been the experience of others (Table VII), although it was not a notable feature

TABle VII.-Relationship Between Age and Mortality Rate in Pneumococcal Meningitis. Percentages Calculated from Figures Given by Various Authors

\begin{tabular}{|c|c|c|c|c|c|}
\hline \multirow[b]{2}{*}{ Authors } & \multicolumn{5}{|c|}{ Mortality in Ages (Years) } \\
\hline & $\begin{array}{l}\text { No. of } \\
\text { Cases }\end{array}$ & $\begin{array}{l}\text { Under } \\
40\end{array}$ & $\underset{40}{\text { Over }}$ & $\begin{array}{c}\text { Under } \\
50\end{array}$ & $\begin{array}{c}\text { Over } \\
50\end{array}$ \\
\hline 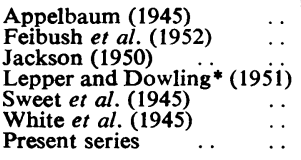 & $\begin{array}{r}67 \\
22 \\
125 \\
43 \\
56 \\
50 \\
78\end{array}$ & $\begin{array}{l}44 \% \\
43 \% \\
67 \% \\
68 \% \\
41 \%\end{array}$ & $\begin{array}{l}73 \% \\
80 \% \\
76 \% \\
89 \% \\
74 \%\end{array}$ & $\begin{array}{l}54 \% \\
44 \% \\
23 \% \\
52 \% \\
40 \%\end{array}$ & $\begin{array}{l}72 \% \\
85 \% \\
41 \% \\
88 \% \\
81 \%\end{array}$ \\
\hline
\end{tabular}

* Not including chlortetracycline-treated cases.

of the series of Smith et al. (1946). Very young patients had a poor prognosis before penicillin became available (Cooke, 1941 ; Waring and Weinstein, 1948 ; Jackson, 1950), but the prognosis for infants when penicillin is used appears fairly good. With penicillin treatment, Waring and Weinstein (1948) noted a $69 \%$ recovery for patients under 2 years old (58 cases), while Nemir and Israel (1951) lost only one of nine infants, and Ross and Burke (1946) achieved a recovery of all nine infants. In the present series also the prognosis for infants with penicillin therapy was better than average (Table III).

The commonest predisposing cause of the meningitis in the present series was middle ear and mastoid infection (38\%) (Table IV), but in $33 \%$ no cause could be found. Pneumonia has often been noted as a common if not the commonest cause of pneumococcal meningitis (Table VIII) but accounted for only $10 \%$ of the cases in this series.

Trauma is evidently a rare cause (Tables IV and VIII) but is, however, a very important one, as recurrences are

TABle VIII.-Predisposing Cause of Pneumococcal Meningitis Expressed as Frequency Distribution in Percentages to Nearest Whole Number. Collected Figures of Various Authors

\begin{tabular}{|c|c|c|c|c|c|c|c|c|c|c|}
\hline $\begin{array}{l}\text { Predisposing } \\
\text { Cause }\end{array}$ & $\begin{array}{l}\text { Appelbaum } \\
\text { et al. } \\
\text { (1949) }\end{array}$ & $\begin{array}{l}\text { Dowling } \\
\text { et al. } \\
(1942)\end{array}$ & $\begin{array}{l}\text { Dowling } \\
\text { et al. } \\
\text { (1949) }\end{array}$ & $\begin{array}{c}\text { Appelbaum } \\
\text { and Nelson } \\
\text { (1945) }\end{array}$ & $\begin{array}{l}\text { Gibson } \\
\text { and James } \\
(1952)\end{array}$ & $\begin{array}{c}\text { Jackson } \\
(1950)\end{array}$ & $\begin{array}{l}\text { Sweet } \\
\text { et al. } \\
\text { (1945) }\end{array}$ & $\begin{array}{l}\text { White } \\
\text { et al. } \\
\text { (1945) }\end{array}$ & $\begin{array}{c}\text { Total, } \\
\text { Excluding } \\
\text { Present Series }\end{array}$ & $\begin{array}{l}\text { Present } \\
\text { Series }\end{array}$ \\
\hline $\begin{array}{l}\text { No. of cases } \\
\text { Middle ear or mas- }\end{array}$ & 125 & 72 & 87 & 67 & 31 & 125 & .56 & 50 & 613 & 78 \\
\hline $\begin{array}{ll}\text { other trauma } & . \\
\text { Others } \\
\text { No cause found }\end{array}$ & $\begin{array}{r}6 \% \\
68 \% \\
38 \%\end{array}$ & $\begin{array}{l}4 \% \% \\
25 \% \\
14 \%\end{array}$ & $\begin{array}{r}2 \% \\
53 \%\end{array}$ & $\begin{array}{r}3 \% \\
3 \% \\
24 \%\end{array}$ & $\begin{array}{l}13 \% \\
23 \% \\
16 \%\end{array}$ & $38 \%$ & $\begin{array}{l}5 \% \\
30 \% \\
20 \%\end{array}$ & $24 \%$ & $\begin{array}{r}3 \% \\
12 \% \\
30 \%\end{array}$ & $\begin{array}{l}12 \% \\
63 \%\end{array}$ \\
\hline
\end{tabular}


apt to occur, especially if the thin floor of the anterior cranial fossa has been fractured. The covering of the damaged bone with a graft of fascia lata proves an effective means of preventing further attacks. Defects in the floor of the anterior cranial fossa causing meningitis may be congenital in origin (Galloway and Chambers, 1953).

Coma and convulsions at the time of admission to hospital indicated a poor prognosis in this series, the difference in mortality between those fully conscious or only stuporous on admission and those having convulsions or comatose being statistically significant. This result might be reasonably anticipated ; it was also found by Lepper and Dowling (i951), but was not confirmed by Feibush et al. (1952) in a small series of cases.

It is apparent from Table $\mathrm{V}$ that those patients who were ill for three days before admission to hospital had the best prognosis. There was only one patient older than 50 years in that group, but even after removing all patients aged 50 or more the mortality for those ill less than three days before admission was $61 \%$ ( 31 cases), for those ill more than three days $24 \%$ ( 21 cases), and for those ill just three days $7 \%$ (14 cases). All the fulminating cases are obviously included in the first group, in which $62 \%$ were in coma or having convulsions when admitted. Twenty-seven per cent. of the 14 cases ill for three days and $52 \%$ of those ill for more than three days before admission to hospital were in coma or having convulsions when admitted. It is probable that more of the last group would have recovered had full medical treatment been started earlier.

Combined sulphonamide and penicillin therapy still remains the treatment of choice in pneumococcal meningitis, and the penicillin should be given by both the intramuscular and the intrathecal routes. Excellent results have been obtained by this method (Ross and Burke, 1946; Smith et al., 1946; Gibson and James, 1952) (Table II). Sulphonamides should be given as for any acute infection, but the daily intramuscular requirement of penicillin is not clear. Smith et al. (1946) were using at first about 120,000 units daily in three- or four-hourly doses or by continuous intramuscular infusion, while Gibson and James (1952) were using latterly $1,600,000$ units daily. As already shown, in the present series those cases receiving more than 250,000 units daily fared no better than those receiving less, and the two groups appear comparable so far as age distribution and level of consciousness on admission to hospital are concerned. Dowling et al. (1949) have said that intrathecal penicillin administration is unnecessary provided that large enough doses are given intramuscularly. They treated 66 cases by the ordinary method and 21 cases without intrathecal therapy and $2,000,000$ units of penicillin every two hours intramuscularly : the mortality of the first group was $66 \%$ and of the second $38 \%$, results which are not good and can hardly be used as an argument for rejecting intrathecal therapy. Smith (1951) found a clinical and bacteriological relapse in a baby with pneumococcal meningitis when given a non-potent dose of intrathecal penicillin in spite of massive intramuscular penicillin dosage every two hours.

In spite of the $75 \%$ cure of 20 cases without intrathecal penicillin by Bunn and Peabody (1952), there is no convincing evidence that intrathecal therapy with penicillin should be abandoned. It should remain part of the routine management in pneumococcal meningitis, and should be given in daily doses of about 20,000 units for about 7 to 10 days or until the meningitis is obviously under control. Much larger doses should not be used, as they are known to produce damage to the spinal cord and cauda equina or even convulsions and death. As little as 50,000 units intraventricularly has produced convulsions (Johnson and Walker, 1945). Gibson and James (1952) thought the dangers were exaggerated and gave even their infants 50,000 units at a single dose.

Although there is no clear-cut evidence in favour of giving very large intramuscular penicillin doses when intrathecal treatment is being given, it is probably wise to give at least $2,000,000$ units daily in divided doses with intervals of not more than four hours between injections. Fortunately the pneumococcus is usually highly sensitive to penicillin and does not develop resistance during treatment.

There is no evidence in the literature that treatment with antibiotics in addition to penicillin will improve the prognosis. On the contrary, there is evidence that the addition of chlortetracycline therapy leads to a worsening of the prognosis. Lepper and Dowling (1951) treated 43 cases with the usual intramuscular and intrathecal penicillin and 14 with the addition of chlortetracycline. In the first group $30 \%$ of the patients died, and in the second $79 \%$, a statistically significant difference.

Surgical treatment for the elimination of foci of infection in the ears, mastoids, or sinuses was regarded as a mainstay of treatment in pneumococcal meningitis before penicillin was available (Neal et al., 1940; Walker and James, 1945), but with the use of penicillin Smith et al. (1946) never found such operations necessary in the acute phase and often not at all. Ross and Burke (1946) found no surgery necessary in their 19 cases. Mastoidectomy was required five times $\mathrm{dn}$ the present series in spite of penicillin therapy. A certain number of recurrences can probably be prevented by the removal of chronic sepsis in ears, mastoids, and sinuses after treatment of the meningitis.

Burr-holes are made in the skull for the intraventricular administration of penicillin or for the diagnosis of an intracranial abscess. Penicillin may be given intraventricularly if a block with exudate prevents its free access to the brain when administered by the lumbar route. Cisternal administration of penicillin may suffice but does not guarantee that it will reach the ventricles. Spinal block is not common in pneumococcal meningitis. Intraventricular penicillin administration was needed in only two of the last 19 cases of Smith et al. (1946) and was required only three times in the present series. Intracranial abscess is also a rare complication. Smith et al. (1946) found this only twice in their 38 cases, and in reviewing the literature Waring and Weinstein $(1948)$ found only $3.6 \%$ of 386 cases and none in 86 treated with both penicillin and sulphonamides.

Pneumococcal meningitis may complicate other and serious diseases as previously shown, when the prognosis is correspondingly poor. The association with diabetes mellitus and hepatic cirrhosis in this series led to diagnostic difficulties and delay in treatment.

\section{Summary}

A short survey of 78 cases of pneumococcal meningitis in the Bristol Clinical Area is presented with a discussion of certain aspects of aetiology, prognosis, and treatment.

The mortality was $49 \%$, or $45 \%$ in 84 attacks of meningitis, as there were some recurrences. The cases were unselected, and included those already with chronic and wasting diseases.

It has been shown that the prognosis was much worse in patients over 50 years of age, but that the results in infants and young children were better than the average ; also that coma or convulsions occurring at the time of admission to hospital influenced the prognosis very unfavourably.

Middle ear or mastoid disease was the commonest primary source of infection, but almost as frequently no source of infection or other predisposing cause could be demonstrated. Pneumonia was an uncommon source of the infection.

Prognosis was worse in those cases with a period of illness greater or less than three days before hospital admission, presumably because the fulminating cases 
were admitted quickly while some of the others were left too late before in-patient treatment was started.

My thanks are due to the consultant medical staff of the Bristol Hospitals for permission to use their records, and especially to Dr. J. Macrae, of the Ham Green Fever Hospital, for his help; to Drs. A. M. G. Campbell and J. K. Lloyd for valuable criticism; and to Dr. G. Herdan for statistical advice.

\section{REFERENCES}

Appelbaum, E. (1945), Clinics, 4, 396.

ADd and Nelson, J. (1945). J. Amer. med. Ass., 128, 778

- and Albin, M. B. (1949). Amer. J. med. Sci., 218, 260

Bunn, P. A., and Peabody, G. (1952). Arch. intern. Med., 89, 736.

Cooke, W. T. (1941). Lancet, $2,510$.

Dowling, H. F., Dauer, C. C., Feldman, H. A., and Hartman, C. R. (1942). New Engl. J. Med., 226, 1015.

Sweet, L. K., Robinson, J. A., Zellers, W. W., and Hirsh, H. L. (1949). Amer. J. med. Sci., 217, 149.

Feibush, J. S., Murphy, E. J., and Lubart, A. (1952). Ann. intern. Med., 37, 65 .

Galloway, W. H., and Chambers, W. (1953). Lancet, 2, 68

Gibson, C. D., and James, D. G. (1952). Ibid., 2, 1203

Hall, W. H., Alden, J., Burt, G. M., and Spink, W. W. (1946). Minn. Med., 29, 553.

Hartmann, A. F., Love, F. M., Wolff, D., and Kendall, B. S. (1945). J. Pediat., 27, 115

Hodes, H. L., Smith, M. H. D., and Ickes, H. J. (1943). J. Amer. med. Ass., 121, 1334.

Jackson, W. P. U. (1950). Arch. Dis. Childh., 25, 22.

Johnson, H. C., and Walker; A. E. (1945). J. Amer. med. Ass., 127, 217

Lepper, M. H., and Dowing, H. F. (1951). Arch. Intern. Med., 88, 489.

J. Pediat 33,336

Neal, J. B., Appelbaum, E., and Jackson, H. W. (1940). J. Amer. med. Ass., 115, 2055.

Israel, J. (1951), Ibid, 147, 213

Rhoads, P. S., Hoyne, A. L., Levin, B., Horswell, R. G., Reals, W. H. and Fox W. W (1940). Ibid 115,917.

Ross, S., and Burke, F. G. (1946). J. Pediat, 29. 737

Ross, $S_{i}$ and Burke, F. G. (1946), J. Pediat

(1951). Practitioner, 166, 334.

Silverthorne, E. S., and Cairns, H. (1946). Lancet, 1, 185

Sweet, L. K., Dumoff-Stanley, E., Dowling, H. F., and Lepper, M. H. (1945). j. Amer. med. Ass., 127, 263.

Toomey, J. A., and Roach, F. E. (1939). Ohio St. med. J., 35, 841

Walker, H., and James, G. W. (1945). Va. med. Mon., 72, 276

Waring, G. W. jun., and Weinstein, L. (1948). Amer. J. Med., 5. 402. Amer. J. med. Sci. 210 , 1

\section{DESACETYLMETHYLCOLCHICINE IN TREATMENT OF MYELOID LEUKAEMIA}

BY

B. J. LEONARD, M.D.

Sybil Mary Pilkington Research Fellow

AND

JOHN F. WILKINSON, M.D., M.Sc., Ph.D. F.R.C.P., F.R.I.C. Physician and Director

(From the Department of Haematology, Manchester Royal Infirmary and Manchester University)

In 1953 Moeschlin and colleagues reported that desacetylmethylcolchicine ("colcemid") had beneficial effects on a group of patients with chronic myeloid leukaemia, while some encouraging results were also noted in a few cases of acute myeloid leukaemia and in two patients in the acute myeloblastic phase of chronic myeloid leukaemia. On the other hand, chronic lymphatic leukaemia failed to respond and might even have been made worse. The profound depressive effects on the granulocytopoiesis were accompanied simultaneously by a reduction in the size of the spleen and an increase in the red blood cell count and haemoglobin values.

Desacetylmethylcolchicine was isolated in a pure form by Santavy and Reichstein (1950) from the mixed alkaloid extract of Colchicum autumnale and was found to have a relatively low general toxicity, some 30-40 times less than colchicine (Schär et al., 1954), which, although having a very marked inhibitory effect on cell mitosis, is too toxic for safe clinical use (Jacobj, 1890 ; Dustin, 1938 ; Bucher, 1939).
Lichtman (1954) has described in detail the effects of desacetylmethylcolchicine on the blood cellular elements in rabbits and cats, producing a diminution of total leucocyte count in two days after intravenous administration and in 12-14 days after oral treatment. With cessation of treatment the leucocytes rapidly returned to normal levels.

We have been able to repeat the observations of Moeschlin and his colleagues in a series of leukaemias and leukaemoid conditions, and are reporting here some of our results with chronic and acute myeloid leukaemias.

\section{Dosage and Control}

The initial oral dose of $3 \mathrm{mg}$. of colcemid daily was increased after three to four days to a total of 7-10 mg. daily according to the white-cell count. This dosage was continued until the leucocytes dropped to approximately 25,000 per c.mm., and was then stopped for three to four days. A daily maintenance dose of 3-5 mg. was then instituted. Daily white-cell counts, platelet counts, and haemoglobin estimations were performed until the maximal effect on the white cells had been attained; thereafter counts were done twice weekly and finally every one to two weeks.

\section{Chronic Myeloid Leukaemia (8 cases)}

Of eight patients with chronic myeloid leukaemia there was a distinct clinical improvement in six (Cases 1-6); their appetites improved, they gained weight and experienced far more energy; their spleens rapidly decreased in size and became barely palpable. In the remaining two (Cases 7

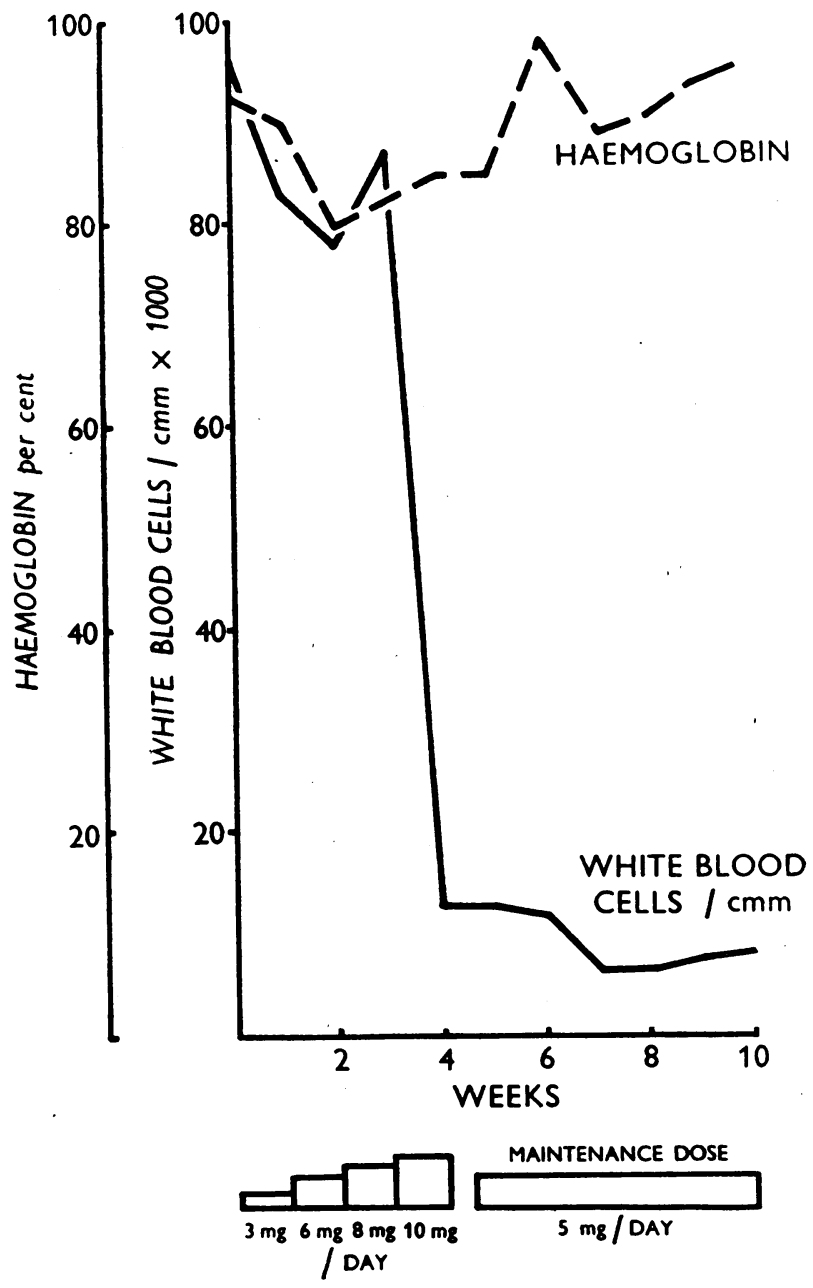

Fig. 1.-Case 6. Effects of colcemid on the total white cells and haemoglobin levels. 